\title{
Occurrence of Bovine Viral Diarrhea (BVDV) and Bovine Infectious Rhinotracheitis (IBR) Virus Infections in Buffaloes in Pernambuco state - Brazil
}

\author{
Larice Bruna Ferreira Soares', Bruno Pajeú e Silva², Jonas de Melo Borges', Júnior Mário Baltazar de Oliveira², \\ Allison Alves de Macêdo ${ }^{2}$, Breno Bezerra Aragão², Sérgio Alves do Nascimento ${ }^{2}$ \& José Wilton Pinheiro Junior ${ }^{2}$
}

\begin{abstract}
Background: Buffaloes are susceptible to viral infections, often associated with pathologies of importance in cattle breeding. Among the numerous infectious diseases, Bovine Viral Diarrhea (BVDV) and Bovine Infectious Rhinotracheitis (IBR) have a negative impact on buffalo creations. This study aimed to detect the occurrence of bovine viral diarrhea virus (BVDV) and infectious bovine rhinotracheitis (IBR) virus infections in buffaloes in Pernambuco state, Brazil.

Materials, Methods \& Results: For this purpose, serum samples were obtained from 244 buffaloes on eight properties distributed in six municipalities. The search for anti-BVDV and -bovine herpesvirus type-1 (BoHV-1) antibodies was performed using the virus neutralization technique. To analyze the association between the serological status of BoHV-1 infection and aspects of hygienic-sanitary and reproductive management, an investigative questionnaire with objective questions was used. In total, 97.9\% (239/244) of buffaloes had anti-BVDV antibodies and 56.1\% (137/244) had anti-BoHV-1 antibodies. Co-infection was observed in 55.3\% (135/244) of buffaloes. The distribution of antibody occurrence in buffaloes by properties ranged from $90.5 \%$ to $100.0 \%$ for BVDV and from $4.8 \%$ to $100 \%$ for BoHV-1. It was not possible to perform an association analysis for BVDV infection; however, in that for BoHV-1 infection, the following variables exhibited a significant association: an extensive breeding system $(P<0.001)$, open herd $(P=0.029)$, lack of reproductive rest $(P=$ 0.029), natural mating in females with reproductive disorders $(P<0.001)$, exploration type $(P=0.0014)$, presence of wild animals $(P<0.001)$, and lack of cleaning facilities $(P=0.008)$.

Discussion: The occurrence of anti-BVDV antibodies in this study was $97.9 \%$ this was higher than those reported in other country's regions. The results of the present study demonstrate a high occurrence of anti-BVDV antibodies in each of the properties in Pernambuco state, demonstrating that the animals have contact with infection sources, due to the large number of positive animals. Indeed, it is likely that there is at least one PI animal in every herd. It was observed that $100 \%$ of the properties possessed at least one positive animal. The high number of positive animal properties may be related to the absence of biosecurity measures; a subclinical BVDV infection can occur which the owners cannot identify it, as it is not common the adoption of a reproductive program in the region. The occurrence of the anti-BoHV-1 antibody in this study was $56.1 \%$. In other states, both lower and higher prevalences were reported compared to this study. The high number of properties with positive animals may be related to several factors, including the ability of the virus to remain latent, thus introducing a single animal infected with BoHV-1 sufficient for infection spread and perpetuation in buffaloes. It is believed that the introduction of infected animals and the lack of disease knowledge by the producers may have been responsible for the agent's introduction and maintenance in the herds. In conclusion, BVDV and IBR virus infections occur in buffaloes in Pernambuco state. Thus, it is suggested that prophylactic measures, including routine diagnosis, reproductive animal control, and strict health care, such as employing cleaning facilities, avoiding contact with neighboring herds, acquiring animals with a negative diagnosis and using an artificial insemination program should be implemented at each property to reduce the reproductive losses caused by these infections.
\end{abstract}

Keywords: diagnosis, BoHV-1, epidemiology.

${ }^{1}$ Departamento de Medicina Veterinária, Universidade Federal Rural de Pernambuco (UFRPE), Unidade Acadêmica de Garanhuns, Garanhuns, PE, Brazil. ${ }^{2}$ Departamento de Medicina Veterinária, UFRPE, Recife, PE. CORRESPONDENCE: L.B.F. Soares [brunaa_soares@ @otmail.com - Tel.: +55 (81) $3320-$ 6441]. Departamento de Medicina Veterinária, Universidade Federal Rural de Pernambuco, Unidade Acadêmica de Garanhuns, Avenida Bom Pastor, s/n. Bairro Boa Vista. CEP 55292-270 Garanhuns, PE, Brazil. 


\section{INTRODUCTION}

Bovine viral diarrhea virus (BVDV) and infectious bovine rhinotracheitis (IBR) virus infections are responsible for several reproductive disorders, which cause a negative impact on buffaloes creation [11,19].

These diseases present a varied distribution in buffaloes, with prevalence ranging from $11.4 \%$ [12] to $84.2 \%$ [4] for BVDV and from $30.5 \%$ [30] to $100 \%$ for bovine herpesvirus type-1 (BoHV-1) [23,29]. In Brazil, studies conducted in different regions indicate prevalences ranging from $8.8 \%$ [8] to $52.7 \%$ [15] for BVDV and 14.7\% [15] to $87.3 \%$ for BoHV-1 [3].

BVD and IBR are diseases requiring notification to the World Organization for Animal Health [38]. Persistently infected (PI) animals are considered the main source of BVDV infection in livestock [37], and studies have already proven the presence of PI animals in buffalo herds [4,19].

Transmission in IBR mainly occurs through contact with secretions [9] and semen [14]. Abortions, limb deformities, birth of weak offspring [11], stillbirths [21], and subclinical infections [29] have been reported in buffaloes.

Considering the development of buffalo breeding and the limited research in relation to infectious diseases affecting the reproductive, this study aimed to diagnose the epidemiological aspects associated with BVDV and IBR virus infection in buffaloes in Pernambuco state.

\section{MATERIALS AND METHODS}

A cross sectional study was carried out in eight properties distributed in six counties in Pernambuco state, Brazil. To compose the study sample, a total of 10,500 heads [20] was analyzed, with an expected prevalence of $51.1 \%$ for BVDV [26] and $79.5 \%$ for IBR [31]. These parameters provided a minimum sample size of 196 for BVDV and 128 animals for IBR, with a $95 \%$ confidence interval, and a statistical error of $7 \%$ [33].

A total of 244 blood samples were collected from the Agrestina $(\mathrm{n}=5)$; Água Preta $(\mathrm{n}=50)$; Canhotinho $(n=21)$; Quipapá $(n=6)$; Ribeirão $(n=$ 113); Rio Formoso $(n=50)$ counties, of reproductive age buffaloes, of dairy and cutting ability, created in a semi-intensive and extensive way, with no history of vaccination against either BVDV or IBR.
Before collecting the biological material, an investigative questionnaire was carried out, consisting of objective questions to the breeder, referring to the property's characteristics, productive, reproductive, and sanitary management, for the association study analysis.

In all, $10 \mathrm{~mL}$ of blood was collected from the tail vein in the coccygeal region, after antibacterial treatment with iodized alcohol, in previously identified siliconized test tubes without coagulant. The tubes were sent to the laboratory for processing. To obtain the serum, the samples were centrifuged at $900 \mathrm{~g}$ for $10 \mathrm{~min}$; the obtained serum was stored in polypropylene microtubes, identified, and maintained at $-20^{\circ} \mathrm{C}$ until processing.

The antibody analysis for BVDV and BoHV-1 was performed by the virus neutralization $(\mathrm{VN})$ technique, according to the protocol established by the World Organization for Animal Health [36]. Serum samples were previously inactivated in a water bath at $56^{\circ} \mathrm{C}$ for $30 \mathrm{~min}$ and then distributed into duplicate 96 well microplates at 1:2 and 1:4 dilutions. The test was performed on MadinDarby bovine kidney (MDBK) continuous lineage cells grown in minimal essential medium (MEM), supplemented with $2 \%$ fetal bovine serum.

As an antigen, a BVDV sample was used at the infecting dose of $100 \mathrm{TCID}_{50}$ per well, to the titration value of $3.16 \times 10^{-4} \mathrm{TCID}_{50}$ whilst BoHV-1, was used at the infecting dose of $100 \mathrm{TCID}_{50}$ per well, previously titrated according to the Reed and Muench technique [25], being evidenced to the titration the value of $6.31 \times 10^{4} \mathrm{TCID}_{50}$.

In all, $50 \mu \mathrm{L}$ of medium per well was distributed in a plate, with the sera mixed in duplicate at a 1:2 and 1:4 dilutions, followed by the addition of $50 \mu \mathrm{L}$ of viral suspension at a $100 \mathrm{TCID}_{50} / 50 \mu \mathrm{L}$ concentration, with a cutoff of 1:4. The plates were then incubated for $1 \mathrm{~h}$ for BVDV and for $24 \mathrm{~h}$ for BoHV-1, in an incubator at $37^{\circ} \mathrm{C}$ and $5 \% \mathrm{CO}_{2}$ and, after the incubation time, $50 \mu \mathrm{L}$ of MDBK lineage cells in $4.5 \times 10^{5}$ per $\mathrm{mL}$ concentration were added, before returning the samples to the incubator for 96 and $72 \mathrm{~h}$ for BVDV and BoHV-1, respectively. To validate the test reliability, cell positive and negative controls were performed, respectively, on each microplate, with the cytopathic effects of these controls being evaluated before the plate samples were read.

For the association between the serological status of BoHV-1 infection and aspects of hygienic- 
sanitary and reproductive management, an interest variables univariate analysis was performed using either Pearson's chi-square test $\left(\chi^{2}\right)$ or the Fisher exact test, when necessary, considering as dependent variable the result obtained in virus neutralization (positive or negative). The EpiInfo ${ }^{\text {TM }} 7$ program was used to perform the statistical calculations and the significance level was set at $5 \%$.

\section{RESULTS}

\section{Bovine Viral Diarrhea Virus (BVDV)}

The occurrence of anti-BVDV antibodies in buffaloes was $97.9 \%(239 / 244)$ [Table 1]. From the eight sampled properties, $100 \%$ had at least one positive animal for this infection. The distribution of antibody occurrence for buffaloes by properties ranged from $90.5 \%$ to $100 \%$ (Table 2). It was not possible to perform the association analysis between the serological status of BVDV infection and the hygienic-sanitary and reproductive management aspects, since all the properties had a high occurrence of positive animals.

\section{Bovine Herpesvirus Type 1 (BOHV-1)}

The occurrence of anti-BoHV-1 antibodies in buffaloes was $56.1 \%(137 / 244)$ [Table 1]. From the eight sampled properties, $100 \%$ had at least one positive animal. The distribution of antibodies occurrence for buffaloes by properties ranged from $4.8 \%$ to $100 \%$ for BoHV-1 (Table 2).

In the association analysis between the serological status and the hygienic-sanitary and reproductive management aspects, a significant association was found for the following variables: an extensive breeding system; an open herd; a lack of reproductive rest; natural mating in females with reproductive disorders; exploration type (mixed); presence of wild animals; a lack of clean facilities (Table 3).

When analyzing the association between the reproductive history for $\mathrm{BoHV}-1$, an association was observed between vaginal discharge $(P=0.036)$ and placental retention $(P=0.036)$.

Co-infection by DVD and BoHV-1 was observed in $55.3 \%(135 / 244)$ from the animals, with antibodies occurring in a range from 4.8 to $100 \%$.

Table 1. Occurrence of bovine viral diarrhea virus (BVDV) and bovine herpesvirus type-1 (BoHV-1) infection in buffaloes by counties in Pernambuco state, Brazil.

\begin{tabular}{|c|c|c|c|c|c|c|c|c|}
\hline \multirow{4}{*}{ County } & \multicolumn{8}{|c|}{ Virus neutralization } \\
\hline & \multicolumn{4}{|c|}{ BVDV } & \multicolumn{4}{|c|}{ BoHV-1 } \\
\hline & \multicolumn{2}{|c|}{ Positives } & \multicolumn{2}{|c|}{ Negatives } & \multicolumn{2}{|c|}{ Positives } & \multicolumn{2}{|c|}{ Negatives } \\
\hline & $\mathrm{AF}$ & $\mathrm{RF}(\%)$ & $\mathrm{AF}$ & $\mathrm{RF}(\%)$ & $\mathrm{AF}$ & $\mathrm{RF}(\%)$ & $\mathrm{AF}$ & $\mathrm{RF}(\%)$ \\
\hline Agrestina & 5 & $100 \%$ & 0 & - & 01 & $20.0 \%$ & 4 & $80.0 \%$ \\
\hline Água Preta & 49 & $98.0 \%$ & 1 & $2.0 \%$ & 26 & $52.0 \%$ & 24 & $48.0 \%$ \\
\hline Canhotinho & 19 & $90.5 \%$ & 2 & $9.5 \%$ & 1 & $4.8 \%$ & 20 & $95.2 \%$ \\
\hline Quipapá & 5 & $100 \%$ & 0 & - & 5 & $100 \%$ & - & - \\
\hline Ribeirão & 112 & $99.1 \%$ & 1 & $0.9 \%$ & 80 & $70.8 \%$ & 33 & $29.2 \%$ \\
\hline Rio Formoso & 49 & $98.0 \%$ & 1 & $2.0 \%$ & 24 & $48.0 \%$ & 26 & $52.0 \%$ \\
\hline Total of samples & 239 & $97.9 \%$ & 5 & $2.1 \%$ & 137 & $56.1 \%$ & 107 & $43.9 \%$ \\
\hline
\end{tabular}

Table 2. Occurrence of bovine viral diarrhea virus (BVDV) and bovine herpesvirus type-1 (BoHV-1) infection in buffaloes by properties in Pernambuco state, Brazil.

\begin{tabular}{ccccc}
\hline \multirow{2}{*}{ Property } & & BVDV & BoHV-1 & \multirow{2}{*}{ Co-infection } \\
\cline { 3 - 4 } & $\mathrm{N}$ & Positivity & Positivity & $5(100 \%)$ \\
A & 5 & $5(100 \%)$ & $19(44.2 \%)$ & $19(44.1 \%)$ \\
B & 43 & $43(100 \%)$ & $1(4.8 \%)$ & $1(4.8 \%)$ \\
C & 21 & $19(90.5 \%)$ & $1(20.0 \%)$ & $1(20.0 \%)$ \\
D & 5 & $5(100 \%)$ & $26(52.0 \%)$ & $25(50.0 \%)$ \\
E & 50 & $49(98.0 \%)$ & $41(83.6 \%)$ & $40(81.6 \%)$ \\
F & 49 & $48(97.9 \%)$ & $20(95.2 \%)$ & $20(95.2 \%)$ \\
G & 21 & $21(100 \%)$ & $24(48.0 \%)$ & $24(48.0 \%)$ \\
H & 50 & $49(98.0 \%)$ & $137(56.1 \%)$ & $135(55.3 \%)$ \\
\hline Total of samples & 244 & $239(97.9 \%)$ & & \\
\hline
\end{tabular}


Table 3. Association analysis between serological status of bovine herpesvirus type-1 (BoHV-1) and hygienic-sanitary management aspects in buffaloes in Pernambuco state, Brazil.

\begin{tabular}{|c|c|c|c|}
\hline \multirow{2}{*}{ Variable } & \multirow{2}{*}{$\mathrm{N}$} & Serology & \multirow{2}{*}{ Value $P$} \\
\hline & & Positive & \\
\hline \multicolumn{4}{|l|}{ Creation System } \\
\hline Semi-intensive & 32 & $9(28.1 \%)$ & $<0.001^{(\mathrm{A})}$ \\
\hline Extensive & 212 & $128(60.4 \%)$ & \\
\hline \multicolumn{4}{|l|}{ Reproductive Management } \\
\hline Natural mount & 194 & $111(57.2 \%)$ & $0.508^{(\mathrm{A})}$ \\
\hline Natural mount + Artificial insemination & 50 & $26(52.0 \%)$ & \\
\hline \multicolumn{4}{|l|}{ Creation Type } \\
\hline Open & 151 & $93(61.6 \%)$ & $0.029^{(\mathrm{A})^{*}}$ \\
\hline Closed & 93 & $44(47.3 \%)$ & \\
\hline \multicolumn{4}{|l|}{ Perform Quarantine } \\
\hline Yes & 11 & $7(63.6 \%)$ & $0.759^{(\mathrm{B})}$ \\
\hline No & 233 & $130(55.8 \%)$ & \\
\hline \multicolumn{4}{|l|}{ Reproductive Rest } \\
\hline Yes & 93 & $44(47.3 \%)$ & $0.029^{(\mathrm{A})^{*}}$ \\
\hline No & 151 & $93(61.6 \%)$ & \\
\hline \multicolumn{4}{|c|}{ Natural Mating in Females with Reproductive Disorders } \\
\hline Yes & 169 & $110(65.1 \%)$ & $<0.001^{(\mathrm{A})^{\prime}}$ \\
\hline No & 75 & $27(36.0 \%)$ & \\
\hline \multicolumn{4}{|l|}{ Exploration Type } \\
\hline Milk & 93 & $44(47.3 \%)$ & \\
\hline Meat & 145 & $87(60.0 \%)$ & $0.001^{(\mathrm{A})^{*}}$ \\
\hline Mixed & 6 & $6(100 \%)$ & \\
\hline \multicolumn{4}{|l|}{ Presence of Wild Animals } \\
\hline Yes & 130 & $91(70.0 \%)$ & $<0.001^{(\mathrm{A})^{*}}$ \\
\hline No & 114 & $46(40.3 \%)$ & \\
\hline \multicolumn{4}{|l|}{ Isolation of Sick Animals } \\
\hline Yes & 56 & $32(57.1 \%)$ & $0.879^{(\mathrm{A})}$ \\
\hline No & 188 & $105(55.8 \%)$ & \\
\hline \multicolumn{4}{|l|}{ Cleaning of Facilities } \\
\hline Yes & 98 & $45(45.9 \%)$ & $0.008^{(\mathrm{A})^{*}}$ \\
\hline No & 146 & $92(63.0 \%)$ & \\
\hline
\end{tabular}

(A)Test $\mathrm{X}^{2}$; (B)Fisher's exact test; $\mathrm{N}=$ samples; *Significant association at $5.0 \%$ level; **Undefined.

\section{DISCUSSION}

\section{Bovine Viral Diarrhea Virus (BVDV)}

This is the first record of the occurrence of anti-BVDV antibodies in buffaloes in Pernambuco state. It is known that the BVDV in buffaloes is distributed worldwide, presenting a variable prevalence from $11.4 \%$ [12] to $84.2 \%$ [4].

The occurrence of anti-BVDV antibodies in this study was $97.9 \%$. This was higher than those reported in other country's regions, as in the Minas Gerais State, 52.7\% (295/329) [15]; in the São Paulo state, $16.3 \%$ (68/417) [24]; in Rio Grande do Sul, $10.8 \%(19 / 176)[28]$ and in the Pará State, $36.0 \%$ $(63 / 175)$ [35].
Differences between serological studies in several parts of the world may occur due to several factors, such as the age of animals, the type of sampling, sanitary and nutritional management, and individual differences between each animal [1].

The results of the present study demonstrate a high occurrence of anti-BVDV antibodies in each of the properties in Pernambuco state, demonstrating that the animals have contact with infection sources, due to the large number of positive animals. Indeed, it is likely that there is at least one PI animal in every herd.

The agent's maintenance in the herds may be mainly related to the presence of persistently infected animals (PI), which eliminate large amounts of the virus in the environment [37], constituting a constant 
source of infection for other animals. Therefore, research must be conducted to identify these PI animals.

It was observed that $100 \%$ of the properties possessed at least one positive animal. In the Ribeira Valley, São Paulo State, the number of properties with positive buffaloes was $100 \%$ [24]. A study carried out in the Pará state indicated a prevalence difference between the properties, with a variation from $0 \%$ to $97 \%$ [35]. The high number of positive animal properties may be related to the absence of biosecurity measures; a subclinical BVDV infection can occur which the owners cannot identify it, as it is not common the adoption of a reproductive program in the region.

Control of BVDV infection must be conducted to systematically reduce the occurrence of an infected herd, prevent contact with PI animals, and with females gestating PI animals is the key to reducing incidence in herds [17]. In Belgium, a study carried out on farms that eradicated BVDV observed that it is still necessary to reinforce basic biosecurity measures, for example, adequate use of protective clothing and avoid contact with neighboring herds [27]. Vaccination of animals is also an important strategy for infection control [32].

\section{Bovine Herpesvirus Type 1 (BOHV-1)}

It is also noted that this is the first record of the occurrence of anti-BoHV-1 antibodies in buffaloes in Pernambuco state. The occurrence of the anti-BoHV-1 antibody in this study was $56.1 \%$ (137/244). In other states, both lower and higher prevalences were reported compared to this study, for example, in Minas Gerais, $14.7 \%$ (38/329) by the $\mathrm{VN}$ test [15] and in Maranhão, $87.3 \%(267 / 306)$ by the ELISA technique [3].

The differences between the results of this study with those carried out in other country regions can be justified by the differences between the hygienic-sanitary management of the herds, age of the animals, reproductive management type [5], production systems, size of the herds [18]. Besides each region's climatic characteristics, geographic factors, exploration type and population sampled [10] are different.

Regarding the number of properties with positive animals, all tested positive for at least one positive animal, like that found in Pernambuco in cattle [31]. In Goiás, $98.5 \%$ of the properties had at least one positive animal [2]. The high number of properties with positive animals may be related to several factors, including the ability of the virus to remain latent, thus introducing a single animal infected with BoHV-1 sufficient for infection spread and perpetuation in buffaloes. In addition to the neglect of bubaline health and lack of knowledge about this infection pathogenesis, associated with the lack of diagnosis and initiatives to implement control and prevention programs [3]. It is believed that the introduction of infected animals and the lack of disease knowledge by the producers may have been responsible for the agent's introduction and maintenance in the herds.

In the association analysis between the serological status and the hygienic-sanitary and reproductive management aspects, a higher frequency of positive animals was observed in the herds that adopted an extensive breeding system $(P<0.001)$; this may occur due to a low control of reproductive diseases, when compared to dairy farming, and may occur because of the agent's introduction into free properties [5]. Another hypothesis, would be the possible contact with neighboring herds, facilitating direct contact with infected animals or the indirect contamination by contaminated water and food [7].

In relation to the type of herd, an association was observed for open herds $(P=0.029)$; this variable was identified as a risk factor in cattle raised in the Paraná state [5]. This association can be attributed to other variables, such as if the animals were purchased at agricultural fairs or not [34]. The animals purchased at fairs was identified as a risk factor in buffaloes, in the Paraíba state, highlighting the importance of performing a sanitary control and serological diagnosis in the purchase of animals, to avoid introduction of infected animals in the herds [8].

The presence of wild animals presented an association $(P<0.001)$ with the positivity in the VN. It can be explained by the fact that, although some animals do not play an important role in the dissemination of BoHV-1, they can take on the role of carrying the virus when moving from one place to another and between properties [34].

Another variable that showed an association with the frequency of positive samples was a lack of cleaning facilities $(P=0.008)$. It is known that the transmission of BoHV-1 can occur through contaminated aerosols and fomites [16] and by contact with respiratory, ocular, and reproductive secretions [9]. In buffaloes, in Paraíba, the presence of sites with water points was a risk factor, probably related to indirect transmission by contaminated water ingestion; these 
animals have a habit of bathing in mud puddles or water points and urinating and defecating, there being ingestion of contaminated water in these places [8]. Corroborating the study that indicates the presence of BoHV-1 buffalo feces, indicative of a source of environmental contamination [29].

Regarding reproductive management, a reproductive absence $(P=0.029)$ and natural mating in females with reproductive disorders $(P<0.001)$ displayed a significant association. This may have occurred due to the use of transfer bulls and by the practice of lending bulls to other properties, which mate with many females, contributing to the spread of BoHV-1 in the herds.

Semen is an important elimination route for BoHV-1, increasing the probability of virus infection on properties that use the practice of natural mating as a reproductive method in herds. Artificial insemination centers may be sure of the agent's absence in the semen [6]. Transmission may also occur by contact with preputial or vaginal mucus [9].

In the herds where the BoHV-1 infection occurred, the animals presented a history of reproductive disorders, such as vaginal discharge $(P=0.036)$ and placental retention $(P=0.036)$. Reproductive disorders and abortions have already been associated with BoHV1 infection in buffaloes, indicating that the virus can be expressed pathogenically in buffaloes [11].

Co-infection was observed in $55.3 \%$ (135/244) of the animals. This result may be associated with the ability of BVDV to cause immunosuppression in animals, facilitating the maintenance of BoHV-1 in herds [13]. In a study carried out in buffalo herds, in Paraíba and Pará state, respectively, a co-infection was observed between BVDV and BoHV-1 [8,35].

Finally, several prophylactic measures could be introduced including diagnosing infected animals, a strict sanitary management, animals' immunization, reproductive control, animal traffic control, and implementing biosecurity measures [22].

\section{CONCLUSIONS}

This is the first record of BVDV and BoHV-1 infections in buffaloes in Pernambuco state and, from the results obtained verified that BVDV and BoHV-1 infections are distributed in buffaloes in the region. It is recommended that prophylactic measures such as routine diagnosis, reproductive control, and strict health care such as cleaning of facilities, avoiding contact with neighboring herds, acquisition of animals with a negative diagnosis and the use of an artificial insemination program must be implemented in the properties with the purpose of reducing the reproductive losses caused by these infections.

Ethical approval. The project was approved by the Ethics Committee in the Use of Animals of the Federal Rural University of Pernambuco with license $n^{\circ} 121 / 2015$.

Declaration of interest. The authors report no conflicts of interest. The authors alone are responsible for the content and writing of the paper.

\section{REFERENCES}

1 Albayrak H., Özan E., Beyhan Y.E., Kurt M. \& Kiliço lu Y.A. 2012. Serological investigation of some aetiological agents associated with abortion in domestic water buffalo (Bubalus bubalis Linneaus, 1758) in Samsun Province of Northern Turkey. Atatürk Üniversitesi Veteriner Bilimleri. Dergisi. 7(3): 155-160.

2 Barbosa A.C.V.C., Brito W.M.E.D. \& Alfaia B.T. 2005. Soroprevalência e fatores de risco para a infecção pelo herpesvírus bovino tipo 1 (BHV-1) no Estado de Goiás, Brasil. Ciência Rural. 35(6): 1368-1373.

3 Carvalho O.S., Gonzaga L.N.R., Albuquerque A.S., Bezerra D.C. \& Chaves N.P. 2015. Occurrence of Brucella abortus, Leptospira interrogans and bovine herpesvirus type 1 in buffalo (Bubalus bubalis) herd under extensive breeding system. African Journal of Microbiology Research. 9(9): 598-603.

4 Craig M.I., König G.A., Benitezd D.F. \& Draghi M.G. 2015. Molecular analyses detect natural coinfection of water buffaloes (Bubalus bubalis) with bovine viral diarrhea viruses (BVDV) in serologically negative animals. Revista Argentina de Microbiología. 47(2): 148-151.

5 Dias J.A., Alfieri A.A., Ferreira-Neto J.S., Gonçalves V.S.P. \& Muller E.E. 2013. Seroprevalence and Risk Factors of Bovine Herpesvirus 1 Infection in Cattle Herds in the State of Parana, Brazil. Transboundary and Emerging Diseases. 60(1): 39-47.

6 Dias J.A., Alfieri A.A., Médici K.C., Freitas J.C., Ferreira Neto J.S. \& Muller E.E. 2008. Fatores de risco associados à infecção pelo herpesvírus bovino 1 em rebanhos bovinos da região Oeste do Estado do Paraná. Pesquisa Veterinária Brasileira. 28(3): 161-168. 
7 Engels M. \& Ackermann M. 1996. Pathogenesis of ruminant herpesviruses infections. Veterinary Microbiology. 53(1-2): 3-15.

8 Fernandes L.G., Pimenta C.L.R.M., Pituco E.M., Lima Brasil A.W. \& Azevedo S.S. 2016. Risk factors associated with BoHV-1 and BVDV seropositivity in buffaloes (Bubalus bubalis) from the State of Paraiba, Northeastern Brazil. Ciências Agrárias. 37(4): 1929-1936.

9 Franco A.C., Roehe P.M. \& Varela A.P.M. 2012. Herpesviridae. In: Flores E.F. (Ed). Virologia Veterinária. Santa Maria: Editora da UFSM, pp.503-570.

10 Freitas E.J.P., Lopes C.E.R., Moura Filho J.M., Sá J.S., Santos H.P. \& Pereira H.M. 2014. Frequência de anticorpos contra o herpesvírus bovino tipo 1 (BoHV-1) em bovinos de corte não vacinados. Ciências Agrárias. 35(3): 1301-1310.

11 Fusco G., Amoroso M.G., Aprea G., Veneziano V., Guarino A., Galiero G. \& Viscardi M. 2015. First report of natural BoHV-1 infection in water buffalo. Veterinary Record. 177(6): 152.

12 Ghazi Y.A., El-Cherif A.M., Azzam R.A. \& Hussein H.A. 2008. Diagnostic studies on bovine diarrhea infection in cattle and buffaloes with emphasis on gene markes. Global Veterinária. 2(3): 92-98.

13 Headley S.A., Alfieri1 A.A., Fritzen J.T.T., Queiroz G.R., Lisbôa J.A.N., Netto D.P., Okano W., Flaiban K.K.M.C. \& Alfieri A.F. 2014. Concomitant bovine viral diarrhea, mycotoxicosis, and seneciosis in beef cattle from northern Paraná, Brazil. Ciências Agrárias. 35(5): 2563-2576.

14 Kupferschmied H.U., Kihm U., Bachmann P., Muller K.H. \& Ackermann M. 1986. Transmission of IBR/IPV virus in bovine semen: A case report. Theriogenology. 25(3): 439-443.

15 Lage A. P., Castro R.S., Melo M.I.V., Aguiar P.H.P., Barreto Filho J.B. \& Leite R.C. 1996. Prevalence of antibodies to bluetongue, bovine herpesvirus 1 and bovine viral diarrhea/ mucosal disease viruses in water buffaloes in Minas Gerais State, Brazil. Revue d'élevage et médecine vétérinaire des pays tropicaux. 49(3): 195-197.

16 Lemaire M., Pastoret P.P. \& Tlliry E. 1994. Le controle de l'infection par le virus de la rhinotrachéite infectieuse bovine. Annales de Médicine Véterinaire. 138(3): 167-180.

17 Lindberg A. \& Houe H. 2005. Characteristics in the epidemiology of bovineviral diarrhea virus (BVDV) of relevance to control. Preventive Veterinary Medicine. 72(1-2): 55-73.

18 Mainar-Jaime R.C., Berzal-Herranz B., Arias P. \& Rojo-Vázquez F.A. 2001. Epidemiological pattern and risk factors associated with bovine viral diarrhoea (BVDV) infection in a non-vaccinated dairy-cattle population from the Asturias region of Spain. Preventive Veterinary Medicine. 52(1): 63-73.

19 Martucciello A., De Mia G.M., Giammarioli M., Donato I., Lovane G. \& Galiero G. 2009. Detection of bovine viral diarrhea virus from three water buffalo fetuses (Bubalus bubalis) in southern Italy. Journal of Veterinary Diagnostic Investigation. 21(1): 137-140.

20 Ministério da Agricultura, Pecuária e abastecimento. 2015. Rebanho Nacional - Bovinos e Bubalinos. Disponível em: < http:// http://www.agricultura.gov.br >. [Accessed in April 2016].

21 Muylkens B., Thiry J., Kirten P., Schynts F. \& Thiry E. 2006. Bovine herpesvirus 1 infection and infectious bovine rhinotracheitis. Veterinary Research. 38(2): 181-209.

22 Nandi S., Kumar M., Yadav V. \& Chander V. 2011. Serological evidences of bovine herpesvirus-1 infection in bovines of organized farms in India. Transboundary and Emerging Diseases. 58(2): 105-109.

23 Petrine S., Amoroso M.G., Perugini G., Gianfelici P., Corrado F., Bazzucchi M., Paniccià M., Casciari C., Fortunati M., Giammarioli M., Fisichella S., De Mia G.M., Galiero G. \& Cenci T. 2012. Rilievo del bubaline herpesvirus 1 (BuHV-1) in un allevamento di bufali nel centro Italia. Large Animal Review. 18(3): 113-116.

24 Pituco E.M., Del Fava C., Okuda L.H., De Stefano E., Bilinskyj M.C.V. \& Samara S.I. 1997. Prevalência da infecção pelo virus da diarréia viral bovina (BVD) em búfalos (Bubalus bubalis) no Vale do Ribeira, SP, Brasil. Arquivos do Instituto Biológico. 64(1): 23-28.

25 Reed L.J. \& Muench H. 1938. A simple method of estimating 50 per cent end point. American Journal of Hygiene. 27(3): 493-497.

26 Rêgo M.J.P., Batista Filho A.F.B., Oliveira P.R.F., Borges J.M., França C.A.B., Ribeiro C.P., Pituco E.M. \& Pinheiro Junior J.W. 2016. Epidemiological analysis of infection by the bovine viral diarrhea virus on family farms in Brazil. Ciencias Agrárias. 37(6): 4119-4130.

27 Sarrazin S., Cay A.B., Laureyns J. \& Dewulf J. 2014. A survey on biosecurity and management practices in selected Belgian cattle farms. Preventive Veterinary Medicine. 117(1): 129-139. 
28 Scheffer C. M. 2013. Herpesvírus e Pestivírus em Rebanhos Bubalinos do Rio Grande do Sul. 98f. Porto Alegre, RS. Dissertação (Mestrado em Ciências Veterinárias) - Programa de Pós-graduação em Medicina Veterinária, Universidade Federal do Rio Grande do Sul.

29 Scicluna M,T., Caprioli A., Saralli G., Manna G., Barone A., Cersini A., Cardeti G., Condoleo R.U. \& Autorino G.L. 2010. Should the domestic buffalo (Bubalus bubalis) be considered in the epidemiology of bovine herpesvirus 1 infection ? Veterinary Microbiology. 143(1): 81-88.

30 Scicluna M,T., Saralli G., Bruni G., Sala M., Cocumelli C., Caciolo D., Condoleo R.U. \& Autorino G.L. 2007. Epidemiological situation of herpesvirus infections in buffalo herds: Bubaline herpesvirus1 or bovine herpesvirus1 ? Italian Journal of Animal Science. 6(2): 845-849.

31 Silva F.S., Oliveira J.M.B., Batista Filho A.F.B., Ribeiro C.P., Pituco E.M. \& Pinheiro Junior J.W. 2015. Análise soroepidemiológica da infecção pelo herpesvírus bovino tipo 1 (BoHV-1) em bovinos no Estado de Pernambuco. Acta Scientiae Veterinariae. 43: 1324.

32 Soltan M.A., Wilkes R.P., Elsheery M.N., Elhaig M.M., Riley M.C. \& Kennedy M.A. 2015. Circulation of bovine viral diarrhea virus - 1 (BVDV-1) in dairy cattle and buffalo arms in Ismailia Province. The Journal of Infection in Developing Countries. 9(12): 1331-1337.

33 Thrusfield M.V. 2004. Epidemiologia Veterinária. 2nd edn. São Paulo: Roca, 556p.

34 Van Schaik G., Dijkhuizen A.A., Huirne R.B.M., Schukken Y.H., Nielen M. \& Hage H.J. 1998. Risk factors existence of bovine herpesvirus 1 antibodies on nonvaccinating Dutch dairy farms. Preventive Veterinary Medicine. 34(2-3): 125-136.

35 Viana R.B., Del Fava C., Monteiro B.M., Moura A.C.B., Albuquerque R.S., Cardoso E.C., Araújo C.V. \& Pituco E.M. 2016. Ocorrência do vírus da leucose enzoótica dos bovinos (BLV) e de anticorpos contra herpesvírus bovino tipo-1 (BoHV-1) e vírus da diarreia viral bovina (BVDV) em búfalos no Estado do Pará. Acta Scientiae Veterinariae. 44: 1357.

36 World Organisation for Animal Health. 2012. Infectious Bovine Rhinotracheitis/Infectious Pustular Vulvovaginitis. In: OIE Manual of Diagnostic Tests and Vaccines for Terrestrial Animals. 7th edn. Chap. 2.4.13. Paris: OIE, pp.1-17.

37 World Organisation for Animal Health. 2015. Bovine Viral Diarrhoea. In: OIE Manual of Diagnostic Tests and Vaccines for Terrestrial Animals. Chap. 2.4.8. Paris: OIE, pp.1-22.

38 World Organisation for Animal Health. 2017. Listed diseases, infections and infestations in force in 2016. Disponível em: < http://www.oie.int/en/animal-health-in-the-world/oie-listed-diseases-2017>. [Accessed in January 2017]. 